Bryn Mawr College

Scholarship, Research, and Creative Work at Bryn Mawr College

2009

\title{
Athletic Inspiration: Vladimir Nabokov and the Aesthetic Thrill of Sports
}

Tim Harte

Bryn Mawr College, tharte@brynmawr.edu

Let us know how access to this document benefits you.

Follow this and additional works at: http://repository.brynmawr.edu/russian_pubs

\section{Custom Citation}

Harte, Tim. "Athletic Inspiration: Vladimir Nabokov and the Aesthetic Thrill of Sports," Nabokov Studies 12.1 (2009): 147-166.

This paper is posted at Scholarship, Research, and Creative Work at Bryn Mawr College. http://repository.brynmawr.edu/russian_pubs/1

For more information, please contact repository@brynmawr.edu. 


\section{Athletic Inspiration: Vladimir Nabokov and the Aesthetic Thrill of Sports}

"People have played for as long as they have existed," Vladimir Nabokov remarked in 1925. "During certain eras—holidays for humanity—people have taken a particular fancy to games. As it was in ancient Greece and ancient Rome, so it is in our present-day Europe” (“Braitenshtreter - Paolino," 749). ${ }^{1}$ For Nabokov, foremost among these popular games were sports competitions. An ardent athlete and avid sports fan, Nabokov delighted in the competitive spirit of athletics and creatively explored their aesthetic as well as philosophical ramifications through his poetry and prose. As an essential, yet underappreciated component of the Russian-American writer's art, sports appeared first in early verse by Nabokov before subsequently providing a recurring theme in his fiction. The literary and the athletic, although seemingly incongruous modes of human activity, frequently intersected for Nabokov, who celebrated the thrills, vigor, and beauty of sports in his present-day "holiday for humanity" with a joyous energy befitting such physical activity.

Nabokov himself proved an inconsistent, yet zealous athlete. ${ }^{2}$ From his early tennis-playing days at the family estate outside of St. Petersburg to soccer games at the Tenishev School in St. Petersburg to moonlighting as a tennis instructor once in exile, Nabokov took up a wide range of athletic activities with a fervor that can be seen as

\footnotetext{
${ }^{1}$ Translations of passages from this essay are my own. In December 1925 Nabokov delivered this essay, which he initially titled "Play" ("Igra"), to a small literary circle in Berlin organized by Raisa Tatarinov and Iulii Aikhenval'd. A version of the talk, which was devoted mostly to boxing, appeared in a December issue of BoxSport (Berlin) and in the Latvian journal Slovo. For a very recent English translation of "Breitensträter - Paolino," see Vladimir Nabokov, "Breitensträter - Paolino," Anastasia Tolstoy and Thomas Karshan, trans., Times Literary Supplement, August 1 2012. In an otherwise excellent translation, Tolstoy and Karshan's work betrays a somewhat dismissive attitude toward athletics, given how they swing and miss when translating several of the boxing terms Nabokov uses, for instance "nyrki'," which are not "dives," as they would have it, but rather "bobbing," while "naotmash"” are not "swipes" but "uppercuts." 2 "I was an erratic but rather spectacular goalkeeper" (Strong Opinions, 59), Nabokov noted, somewhat ironically, in 1965.
} 
nearly rivaling his other chief early interests, lepidoptera and literature. In addition to tennis and boxing, Nabokov played goalkeeper on teams in England and Germany in the 1920s and early 1930s. ${ }^{3}$ Nabokov's involvement in athletics may have waned as his literary career evolved, yet he long maintained an impassioned observer's admiration for sports that would inform many of his works.

Nabokov's athletic outlook reflected a broader preoccupation with games and play. Whether penning chess problems, chasing butterflies, or playfully toying with his readers, Nabokov engaged in games and gamesmanship in ways that complemented his personal zeal for competitive sports. ${ }^{4}$ Indeed, Nabokov did not just participate in athletic games; rather, he repeatedly probed with words the intense experience of athletic competition and strove to involve his readers in this active, invigorating experience. By placing such a conspicuous emphasis on sports competition in both his poetry and prose, Nabokov encouraged his readers' vicarious, spectatorial involvement in a wide range of fictional athletic contests. Hence Nabokov highlighted the act of watching athletes in action, implicitly equating his own audience to sports spectators. Through the prism of literature, Nabokov celebrated the ability of sports to stir the imagination and transform ordinary, physical reality into an active, joyful, and ultimately revelatory experience for not only athletes, but also spectators and, it follows, writers and readers.

\footnotetext{
${ }^{3}$ Nabokov, Brian Boyd documents, played goalkeeper for a Russian Sports Club in Berlin between 1931 and 1932 and in one game was knocked unconscious diving for the ball, prompting Vera Nabokov to insist that her husband give up the sport. Brian Boyd, Vladimir Nabokov: The Russian Years (Princeton: Princeton University Press, 1990), pp. 376-77.

${ }^{4}$ As Aleksandr Dolinin aptly notes, Nabokov "highly valued the magic of play that is based on deception, illusion, impersonation, and he himself was a connoisseur of various forms of play-the play of nature, the play of words and the mind, the play of chess pieces" (Dolinin, 21). For a comprehensive study of Nabokov's unique approach to play, see Karshan, Vladimir Nabokov and the Art of Play (New York: Oxford University Press, 2011).
} 
Various critics have noted the motif of sports in Nabokov's work, yet rarely has it been analyzed in any depth. ${ }^{5}$ In one of the few sustained critical treatments of Nabokov's focus on athletics, William Rowe sees Nabokov's descriptions of sports as explicit metaphors for sex, more often clever punning rather than a poignant tribute to athleticism. In regard to Lolita, for example, Rowe remarks that "sports assume a subtly symbolic sexual significance" (Rowe, 143). In Rowe's analysis, the tennis of Lolita entails a physicality that is far more erotic than athletic, as he claims that "it seems possible to construe 'a rally' as a single sex act" and "winning... as attaining a climax" (Rowe, 145). Rowe, whose analysis Nabokov vehemently refuted, likewise discerns the erotic in later sports references from Pale Fire and $A d a{ }^{6}$

More recently, David Larmour has analyzed various sports scenes found throughout Nabokov's early Russian novel Glory (Podvig, 1932), and, like Rowe, he highlights the sexual in these scenes. Nabokov, Larmour argues, "links sports and sex in a nexus of semiological significance" (Larmour, 63). Accordingly, Larmour underscores associations of the soccer goal to the vagina in Glory and the suggestion of sports as a metaphor for sexual arousal, in particular Nabokov's mention of Martin, the protagonist of the novel, keeping "his goal virgin to the end of the game" and how, when daydreaming of soccer yet "afraid to reach the delicious essence too quickly, [Martin] would dwell in detail on the pregame preparations" (Glory, 111, 109). Larmour links almost every sports passage in Glory with Martin's sexual awakening and activity, and

\footnotetext{
${ }^{5}$ D. Barton Johnson offers a cursory, dismissive mention of "Breitensträter - Paolino" and its place in Nabokov's oeuvre: "Apart from a very few flashes, the [essay's] whole is stylistically flat and reeks of what now seems like adolescent machomania." D. Barton Johnson, "The Latvian Nabokov: 'Breiterstrater - Paolino' \& 'Tokalosh'," The Nabokovian 34 (Spring 1995): 33. A brief, yet informative discussion of Nabokov and sports, however, can be found in Gavriel Shapiro, The Sublime Artist's Studio: Nabokov and Painting (Evanston, Illinois: Northwestern University Press, 2009), p. 168.

${ }^{6}$ In 1971 Nabokov published a fierce rebuttal to Rowe's Nabokov's Deceptive World in The New York Review. Criticizing a variety of Rowe's Freudian associations, Nabokov noted the "ludicrous" nature of Rowe's analysis, particularly "his examination of Lolita's tennis and his claim that the tennis balls represent testicles (those of a giant albino, no doubt)" (Strong Opinions, 306).
} 
while such linkages have some validity, they distort the broad emphasis on sports in this early Nabokov novel. Ultimately, Larmour's reading, like Rowe's, proves reductive and ignores the athletic beauty and joy that Nabokov strove to convey to his readers.

Thomas Karshan, providing a more straightforward analysis of Nabokovian athletics than that found in Rowe and Larmour's work, has drawn significantly upon Nabokov's essay “Breitensträter - Paolino” (1925)— Nabokov's vivid account of a heavyweight boxing match he attended at Berlin's Sports Palace (Sportpalast) between the German Hans Breitensträter and the Basque Paolino Uzcudun-to explore the treatment of play and games in Nabokov's prose. ${ }^{7}$ Karshan argues that Nabokov assumes a playful fictional voice in "Breitensträter - Paolino" (or "Play" ["Igra"], as Nabokov originally called his essay on boxing) and thus engages in a somewhat deceptive game when extolling the virtues of the crowd and remarking that this boxing crowd "has nothing in common with the so-called rabble and, far more than the throngs welcoming home national heroes, is enveloped by a pure, sincere, and good natured delight" ("Braitenshtreter - Paolino," 750). Karshan hypothesizes that such views could not possibly be Nabokov's own, since the narrator of "Breitensträter - Paolino" relishes the crowd's delight at the violent, gripping action, a stance Karshan sees as antithetical to Nabokov: "His sentiment of solidarity with the crowd is very un-Nabokovian" (Karshan, “December 1925," 11). Elsewhere, Karshan argues that Nabokov strives "to vindicate competition and therefore violence so as to reject communist utilitarianism" (Karshan, Art of Play, 88). Yet Nabokov, who attended boxing matches with the enthusiasm and knowledge of a true devotee, did indeed find value in the energy and sense of communion that often arose within the engaged crowd at popular sporting events, such that he

\footnotetext{
${ }^{7}$ For more on this bout's Berlin context, see Dieter E. Zimmer, Nabokovs Berlin (Nicolai: Berlin, 2001).
} 
frequently sought to evoke in his work this communal feeling so unique to the sports spectator. ${ }^{8}$ Like the leftist Bertolt Brecht, who similarly frequented boxing matches at the Berlin Sports Palace in the 1920s, Nabokov found the excitement and drama of these matches extremely compelling, the ideal fodder for his art, irrespective of any politics. ${ }^{9}$

A celebration of the voyeuristic thrills of sports spectatorship, "Breitensträter Paolino" depicts the Berlin boxing crowd as virtually participating in the action. Recounting his attendance at the December 1925 bout, Nabokov notes, "With every blow received by Breitensträter, my neighbor inhaled with a whistle, as if he himself received these blows, and the entire darkness and all the tiers grunted with a certain sort of huge, supernatural grunt" ("Braitenshtreter - Paolino," 753). The crowd suffers vicariously through the travails of the hometown favorite, as if Breitensträter's setbacks are its own. And from out of the crowd arises a "supernatural grunt," whereby the communal murmuring of those present at the bout hints at the ability of sports spectators to experience something highly physical and rough, but also profound and even transformative. Rather than mocking fans or using sports as a mere backdrop for his narrative games, as Karshan would have it, Nabokov derived great joy from the athletic spectacle, particularly as a spectator who could be elevated to the "supernatural" heights experienced in Berlin. It thus comes as no surprise that Nabokov would attempt to replicate this sense of vicarious athletic participation—and heartfelt appreciation for sports-in his poetry and fiction.

\footnotetext{
${ }^{8}$ In "Breitensträter- Paolino" Nabokov notes that he attended bouts of some of his era's most famous boxers: "I was lucky enough to see Smith, Bombardier Wells, Goddard, Wilde, Beckett, and the marvelous Carpentier, who defeated Beckett" ("Braitenshtreter - Paolino," 751).

${ }^{9}$ For more on the importance of boxing in Brecht's work, see Ole Gram, "Left Hook: Brecht, Boxing, and Committed Art," Xcp, vol. 9 (2001): 7-16. Also see Wolf van Eckardt and Sander L. Gilman, Bertolt Brecht's Berlin: A Scrapbook of the Twenties (Garden City, New York: Anchor Press, 1975), pp. 136-38.
} 
Hans Ulrich Gumbrecht, offering a useful paradigm for active, discerning appreciation of sports in his 2006 In Praise of Athletic Beauty, has probed what he sees as the aesthetic pleasure underlying sports spectatorship. Bemoaning the tendency of scholars "to enlighten us with their opinion that sports are something different from what they appear to be" (Gumbrecht, 27), Gumbrecht emphasizes the aesthetic experience of observing sports and "the joy we feel when we watch an athletic event" (54). Participatory thrills - a form of epiphany for Gumbrecht and something close to what Nabokov experienced with sports—come from witnessing the awe-inspiring performances of great athletes. Gumbrecht thus expresses deep gratitude toward these athletes for the beauty of their physical prowess and the heightened aesthetic pleasure they elicit in audiences.

At the heart of In Praise of Athletic Beauty, Gumbrecht delineates seven aesthetic "fascinations" that captivate audiences at sporting events and provide "a source of joy" (Gumbrecht, 150) for those in attendance. These seven fascinations—which prove quite germane when exploring Nabokov's own celebration of sports-arise out of wondrous appreciation for the following facets of athletic performance: 1) the sculpted bodies in the sporting arena; 2) the suffering of athletes who face defeat and potential death; 3) the aesthetic grace of athletic movement; 4) the deft use of tools—or equipment—such as gloves and bicycles to enhance the body's potential; 5) the capability of athletes to supersede established practices in sports requiring a prescribed form; 6) the epiphany of form produced by stunning athletic play(s); and 7) the exquisite timing of athletes (Gumbrecht, 153-201).. Through a combination of these fascinations, Gumbrecht argues, we are drawn to competitive sports, as we participate vicariously through our observation and derive immense pleasure when witnessing the exploits of athletes. 
Nabokov's admiration for sports, particularly as it was presented in "Breitensträter - Paolino," anticipates the majority of Gumbrecht's fascinations. Like Gumbrecht, Nabokov emphasizes throughout "Breitensträter - Paolino" the artistry and sculpted beauty of athletes. He focuses, for instance, on Paolino's massive torso: "Paolino appeared first in the ring and sat down, as is customary, on his corner stool. Huge, with a dark, square head, and in a splendid heel-length robe, this Basque boxer resembled an Eastern idol” ("Braitenshtreter - Paolino," 752). The eventual winner of the bout, Paolino appears before Nabokov and his fellow fans as a larger-than-life deity. Elsewhere, Nabokov notes that "in the silence a boxing glove, shiny from all the sweat, succulently smashed against the lively, naked body" ("Braitenshtreter - Paolino," 753). In highlighting the aesthetic appeal of the boxers' size, physique, and impressive aura, Nabokov places the combatants at a mystical remove from the crowd and himself, yet he also suggests that the crowd — and, it follows, his readers — might savor the physical action and beauty on display in the ring.

Nabokov, like Gumbrecht, presents competitive athletics as a source of great beauty, for he accentuates the aesthetic nature of sports throughout "Breitensträter Paolino." Revealing an impressive familiarity with the nuances of boxing, Nabokov, for instance, discerns subtle artistry in the sport: "The heart of the matter, firstly, lies in the beauty of the very art of boxing, in the absolute precision of lunges, sidesteps, bobbing, and the most diverse punches: hooks, jabs, uppercuts - and, secondly, in that wonderful manly emotion that this art form arouses" ("Braitenshtreter - Paolino," 750). In addition to delighting in the "manly emotion" (a focus on machismo found in various early works by Nabokov), Nabokov presents the boxing as an "art form" capable of evoking a wide, powerful range of sensations, as if the "absolute precision" of the "most diverse punches" 
can be roughly equated with his own emerging skills as a writer. Through his deft writing, Nabokov hopes to elicit in his readers a heightened sense of involvement with and appreciation for the boxers' own deft moves and artistry.

Once Nabokov shifts to the Berlin bout's denouement, his inspired account of the boxing reveals an undeniable fascination with the conspicuous suffering that befalls the vanquished in the boxing ring:

After eight seconds [Breitensträter] rose with a colossal effort and dragged himself to his stool. He miraculously endured the eighth round, amidst rising peals of applause, but at the start of the ninth round, Paolino, hitting him under the chin, landed just the punch he wanted. Breitensträter crumpled. The darkness roared violently and discordantly. Breitensträter lay curled up. The referee counted down the fateful seconds. The German continued to lie there.

("Braitenshtreter - Paolino," 753)

Nabokov places the inevitable agony of the defeated boxer at the climax of his essay, as he describes - and even relishes - the aggressive, discordant response of the crowd to the definitive knockout of the German pugilist. Despite the brutality and harsh, bloody veneer of the boxing, Nabokov perceives a lyrical poignancy-or pathos-within the intense athletic battle.

At the conclusion of "Breitensträter - Paolino," in accordance with the expressivity he attributed to boxing, Nabokov emphasizes the uplifting thrills he and other fans communally experience upon witnessing such intense, exhilarating play:

The competition came to an end, and when we all poured out onto the street and into the frosty blue light of a snowy night, I am sure that ... in the souls and muscles of the entire crowd, which tomorrow morning would disperse to offices, shops, and factories, there was a general feeling of wonder, which surely justified matching up these two great boxers, for this was a feeling of confident, sparkling strength, vivacity, and courage, all infused with the sense of play inherent to the boxing. And this playful feeling is perhaps more essential and purer than many of life's so-called "lofty pursuits." ("Braitenshtreter - Paolino," 754)

By emphasizing the reverberation of athletic action through the "souls and muscles" of the diverse boxing crowd, Nabokov discerns within the Berlin fans a union of the 
aesthetic ("souls") and the physical ("muscles"). A "general feeling of wonder" and, it seems, gratitude have arisen out of the "strength, vivacity, and courage" actively experienced by all the spectators. Insinuating that athletic play could surpass high culture ("life's so-called 'lofty pursuits"'), Nabokov proposes that audiences—whether the crowd or readers - might derive something "more essential and purer" through the "playful feeling" of sports. Hence Nabokov would amplify the intersection of athletics and literature in subsequent work, as he strove to replicate for readers the profound, joyful effect sports could indeed have on spectators.

\section{Literature and Sports}

Sports, Nabokov emphasized, could contribute to the effectiveness and power of literature. Although athletics generally constitute a highly kinetic form of human activity, while literature entails something more sedentary and cerebral, Nabokov saw sports as providing literature a special form of energy and inspiration that readers-much like spectators—might relish. In "Breitensträter - Paolino," for instance, Nabokov notes that Bernard Shaw, Jack London, Arthur Conan Doyle, and Aleksandr Kuprin all drew upon the romance and beauty of boxing in their fiction, while Nabokov himself, in addition to including sports as a frequent theme in his own work, used his lectures on Russian and European literature to dwell at length on Tolstoy's attention to skating and tennis in Anna Karenina. ${ }^{10}$ Discussing Cervantes's Don Quixote, Nabokov would even score the eponymous hero's victories and defeats like a tennis game to highlight the

\footnotetext{
${ }^{10}$ Nabokov, Lectures on Russian Literature, ed. Fredson Bowers (New York: Harcourt Brace Jovanovich/Bruccoli Clark, 1981), p. 234. "Court-tennis," Nabokov remarks in his discussion of Anna Karenina, "is mentioned both by Shakespeare and Cervantes. Ancient kings played it, stamping and panting in resounding halls. But this [lawn tennis], I repeat, is our modern game."
} 
proto-athletic nature of the novel's plot. ${ }^{11}$ Or consider Nabokov's American novel Pnin (1957), in which the central, eponymous protagonist Timofey Pnin, in addition to enduring a long linguistic ordeal when purchasing a soccer ball, delivers a lengthy monologue on sports and literature. ${ }^{12}$ Using the Russian term for boxing, box, Pnin notes the emergence of athletics as a motif in his native country's literature: "The first description of box in Russian literature we find in a poem by Mihail Lermontov ... The first description of tennis ... is found in Anna Karenina, Tolstoy's novel, and is related to year 1875"” (Pnin, 105-06). ${ }^{13}$ For Nabokov (and Pnin), sports were not merely some minor theme but rather a germane contribution to fiction's historical, narrative, and philosophical fabric, as Nabokov allowed his readers to revel like spectators in the vigor, playfulness, and competitive spirit of sports.

In Nabokov's work, the linking of the athletic, the literary, and issues of spectatorship appeared as early as 1920 in the poem "Football."14 Throughout the seven

\footnotetext{
${ }^{11}$ Nabokov, Lectures on Don Quixote, ed. Fredson Bowers (New York: Harcourt Brace Jovanovich/Bruccoli Clark, 1983), pp. 89-112.

${ }^{12}$ Preparing for the arrival of Victor Wind, the fourteen year-old son of ex-wife Liza, Pnin enters a sporting goods store to buy the soccer ball for his young visitor. Requesting a "football," since he remains unaware of the American distinction between soccer and football, Pnin is surprised to be handed an egg-shaped leather ball: “'No, no,' said Pnin, 'I do not wish an egg or, for example, a torpedo. I want a simple football ball. Round!" (Pnin, 99). Pnin's "football ball," of course, reveals his difficulties with the English language (he translates too literally futbol'nyi miach, Russian for "soccer ball"). The ensuing description of Pnin in the sporting goods store also accentuates the novel's conspicuous blend of athletics and literature: "And with wrists and palms he outlined a portable world. It was the same gesture he used in class when speaking of the 'harmonical wholeness' of Pushkin" (Pnin, 99). As Nabokov's narrator emphasizes, Pnin forms with his hands the shape of a soccer ball, a "portable world" of athletics (and literature) that has traveled with the émigré Pnin from Russia to the U.S., which in turn is linked by the narrator-and Pninto Pushkin's vision of harmony. Ultimately, the soccer ball, which Pnin never gives to the unathletic Victor, will end up in Pnin's yard, where our attention is directed toward "a brand-new, unwanted soccer ball that had recently rolled into the water from the sloping lawn after Pnin disposed of it by defenestration" (Pnin, 109), a telling, metonymic image of Pnin's thwarted dreams of Pushkinian harmony. ${ }^{13}$ For "box," Pnin has in mind Lermontov's “A Song about Tsar Ivan Vasilyevich, His Young Bodyguard, and the Brave Merchant Kalashnikov," (1838), a narrative poem also alluded to in "Breitensträter Paolino," while his mention of tennis in Anna Karenina appeared in much fuller form in Nabokov's own lectures on Tolstoy.

${ }^{14}$ Both "Football" and "Lawn Tennis" (1920) are Russian poems by Nabokov that feature English titles, which thus reflect the anglo-centric nature of Nabokov's interest in sports. For a discussion of
} 
stanzas of this semi-autobiographical poem, Nabokov describes a soccer match, during which the first-person narrator-a goalkeeper-watches as a young woman arrives at the match with a male companion. The narrator imagines her asking this companion about the thin goalkeeper (the narrator), who confidently parries the soccer ball's "headlong flight" ("stremitel'nyi polet"). Once the woman departs, the poem concludes with the narrator-goalkeeper's sudden transition from the here-and-now of soccer into the lofty realms of poetry and posterity:

А там все прыгал мяч, и ведать не могли вы, Thus the ball bounded, and you could not know что вон один из тех беспечных игроков, that over there one of those carefree players, в молчанье, по ночам творит,-неторопливый- in silence, composes at night—so deliberateсозвучья для иных веков. ${ }^{15} \quad$ Harmonies for other eras.

Neither the woman nor her male companion will learn that the goalkeeper is in fact by night a poet producing verse destined for posterity (“other eras"), but they do witness his artistry in goal. The bounding of the ball precipitates a thematic jump into the eternal realm of art, for Nabokov, as he will do in subsequent work, suggests that athletics foster creative energy, whereby the physical artistry of the goalkeeper's athletic saves anticipates the "harmonies" of the poet-goalkeeper's verse.

Although appearing long after "Football," Nabokov’s autobiographical Speak, Memory (1966) likewise accentuates the beneficial influence of sports on the literary. In childhood reminiscences from Speak, Memory, for instance, Nabokov describes the fencing and boxing he observed his father practicing at their St. Petersburg home in the family library, where "the scholarly and the athletic" merged to stir the senses of the young writer-to-be:

\footnotetext{
"Olympicum," an unpublished poem devoted to athletics that Nabokov wrote while studying in England, see Karshan, Vladimir Nabokov and the Art of Play, pp. 65-66.

${ }^{15}$ Nabokov, "Football," Sobranie sochinenii russkogo perioda v piati tomakh, vol. 1, p. 530.
} 
There, I would find my father, a big, robust man, looking still bigger in his white training suit, thrusting and parrying, while his agile instructor added brisk exclamations ('Battez!' 'Rompez!') to the click-clink of the foils. Panting a little, my father would remove the convex fencing mask from his perspiring pink face to kiss me good morning. The place combined pleasantly the scholarly and the athletic, the leather of books and the leather of boxing gloves (Speak, Memory, 181).

Already an engaged spectator of sports, the adolescent Nabokov cherishes his father's athletic activity (the clinking of swords, the perspiration) while duly noting the compelling union of books and sports through the "pleasantly" evocative leather.

Moreover, Nabokov goes on to recall that, long after the dismantling of his family's library, he discovered in the New York City Public Library a copy of his family library's catalogue his father had printed "when the phantom books listed therein still stood, ruddy and sleek, on his shelves" (Speak, Memory, 182). In a fitting example of anthropomorphic detail, the books themselves- "ruddy and sleek" and perhaps a metonymic reflection of the elder Nabokov with his "perspiring pink face"-have gained vigor from all the strenuous athletic activity in the library. ${ }^{16}$

In Speak, Memory the most explicit celebration of sports and their influence on the literary comes when Nabokov fondly recounts his time as goalkeeper on a soccer team at Cambridge University's Trinity College, where he studied and lived between 1919 and 1922. Quite tellingly, Nabokov begins these recollections by noting that "the literary set... while commending my nocturnal [literary] labors, frowned upon various

\footnotetext{
${ }^{16}$ Another merging of the literary and athletic in Speak, Memory occurs when Nabokov sums up his reminiscences of Cambridge University with a list of recollections from his student days. In addition to tennis, alpinism, and Joyce's Ulysses, Nabokov recalls that an old waiter spilled "soup in Hall on the Professor A. E. Housman" and that "E. Harrison unexpectedly [made] me a present of The Shropshire Lad, a little volume of verse about young males and death" (Speak, Memory, 273). Although Nabokov does not make the connection explicit, Housman penned The Shropshire Lad, a "little volume of verse" (published in 1896) devoted, in part, to athletics. From "To an Athlete Dying Young," the collection's most famous poem, to "Is My Team Ploughing," Housman's verse captures the English cult of athletic competition at the time while also exemplifying the ability of literature to convey cherished moments on the playing field.
} 
other things I went in for, such as entomology, practical jokes, girls, and, especially, athletics" (Speak, Memory, 267). For most members of Nabokov's intellectual circle, literature and sports prove incongruous, yet for Nabokov they merge, as soccer games paradoxically provide an opportunity for Nabokov to hone his poetic sensibilities. In England, the crowd's "thrilled adulation" typically afforded the "gallant art" of goalkeeping in "Russia and Latin countries" (Speak, Memory, 267) eludes Nabokov, and thus one "art" form gives way to another. Although experiencing "bright days—-the good smell of turf, that famous inter-Varsity forward dribbling closer and closer to me with the new tawny ball at his twinkling toe, then the stinging shot, the lucky save, its protracted tingle," he often encounters "more memorable, more esoteric days" when he struggles in goal with his "head racked with neuralgia after a sleepless night of verse-making" (Speak, Memory, 267-68). The late-night writing and "esoteric," solitary bursts of creativity may trigger headaches in the young goalkeeper and contribute to many a ball getting past him, but the soccer itself offers the poet what he retrospectively sees as the "luxury" to develop his fertile imagination while play unfolds at the opposite end of the pitch:

The far, blurred sounds, a cry, a whistle, the thud of a kick, all that was perfectly unimportant and had no connection with me. I was less the keeper of a soccer goal than the keeper of a secret. As with folded arms I leant my back against the left goalpost, I enjoyed the luxury of closing my eyes, and thus I would listen to my heart knocking and feel the blind drizzle on my face and hear, in the distance, the broken sounds of the game, and think of myself as of a fabulous exotic being in an English footballer's disguise, composing verse in a tongue nobody understood about a remote country nobody knew. Small wonder I was not very popular with my teammates. (Speak, Memory, 268)

The line between sports and art blurs here: from out of the rainy setting, the "thud" of the distant soccer ball, and the "knocking" heart of the goalkeeper arise the young Nabokov's literary "secret," his creativity, and a most vigorous celebration of artistic consciousness, 
all of it inspired by athletic play. And Nabokov compels readers to go from beholding his goalkeeping prowess to beholding his literary prowess.

\section{Dreams of Glory}

The prominent position Nabokov reserved for athletics in his work stemmed in large part from what he saw as the capability of competitive sports to stir the imagination and dreams of athletes, spectators, and readers alike. For Nabokov, the athletic body and its beauty indeed provided an ideal springboard for human imagination and creativity. In a series of poems devoted to sports and in Nabokov's early novel Glory, dreams, imagination and their elicitation through competitive sports underlie the transformation of athletics into art. Nabokov's athletic personae imaginatively envision victory and success on a variety of fronts, while those witnessing the athletics likewise find creative inspiration in what they see. Hence Nabokov repeatedly conveys to readers his aesthetic exuberance at beholding athletes supersede their physical limits and transcend everyday reality, whether by means of athletic prowess or a vivid imagination, as the intensity of the game gives rise to impressive acts of creativity and, it follows, art.

Nabokov's ardent interest in athletics and their ability to inspire emerged early on in his poetry. Consider, for instance, "The Bicyclist" ("Velosipedist," 1918), a poem in which Nabokov presents his $1^{\text {st }}$-person cyclist as both athlete and enthralled observer. Here the thrills of physical activity merge with vibrant dreams, a crucial link that will continue in Nabokov's subsequent prose. Evoking the spirit of the symbolist Aleksandr Blok and his 1903 poem "I Dreamed of Cheerful Thoughts...” (“Mne snilis' veselye 
dumy...”), Nabokov begins “The Bicyclist” by replacing Blok’s romantic mysticism with the romance of the road as experienced from the perspective of a rapidly moving bicycle:

Мне снились полевые дали, дороги белой полоса, руль низкий, быстрые педали, два серебристых колеса.

Восторг мне снился буйно-юный, и упоенье быстроты, и меж столбов стальные струны, и тень стремительной версты. ... ${ }^{17}$
I dreamed of the fielded distances, The white road's stripe, the low handle-bars, the quick pedals, the two silver wheels.

I dreamed of wild-youthful delight, and the ecstasy of speed, and the steel strings between milestones and the shadow of a headlong verst. ...

Here cycling appears as a dream of ecstatic speed and delight, thus underscoring the youthful vigor of athletics as well as the vivid impressions of a fleeting landscape brought on by the bicyclist's headlong rush. The physical thrills of the road occupy a liminal space between mystical, dreamlike euphoria and the tangible, mechanical details of the bicycle itself.

For Nabokov, athletics and athletic spectatorship frequently prompted an impulse toward romantic dreams, as sports in a variety of works present-as well as foster-the courage, pluck, and inspiration necessary for romance and romantic conquest. In $A$ University Poem (Universitetskaia poema), a semi-autobiographical novella-in-verse from 1927, Nabokov highlights the intersection of love and sports for a student like himself at Cambridge University. Comprised of a Pushkin-esque 63 stanzas that lend the themes of both love and sports a lofty, lyrical tenor, A University Poem recounts the firstperson protagonist's courtship of Violet, an Englishwoman in her twenties whose seductive yet beguiling ways persist against a backdrop of, among various popular activities, soccer and tennis. Beginning in stanza 20, the protagonist takes Violet to a

\footnotetext{
${ }^{17}$ Nabokov, "Velosipedist," Sobranie sochinenii russkogo perioda v piati tomakh, vol. 1, p. 543. Nabokov himself admitted that he "went through" a period in the 1910s when Blok got "into [his] system-and everything [else] seem[ed] unblokish and flat." See Nabokov, The Nabokov-Wilson Letters, ed. Simon Karlinsky (New York: Harper \& Row, 1979), p. 94.
} 
local soccer match, where he attempts to synchronize his courting of Violet with events unfolding on the field:

Но вот однажды, помню живо, в начале марта, в день дождливый, мы на футбольном были с ней соревнованье. ...

С самим собою в соглашенье я молчаливое вошел: как только грянет первый гол, я трону руку Виолеты.
But once here, I remember vividly, in the beginning of March on a rainy day I was with her at a soccer match. ...

With myself I entered into a silent pact: as soon as the first goal crashes in, I will touch Violet's hand. ${ }^{18}$

The scoring of the first goal will trigger the protagonist's pursuit of Violet. Although notably a spectator rather than a participant at this soccer game, he takes inspiration from the athletes as he plots his seduction of Violet. The lively soccer crowd will subsequently howl in delight once a "skillful player" ("igrok iskusnyi”) scores the first goal, yet Violet spurns the protagonist's ensuing advances, remarking in stanza 22: “'Over there that one plays worst of all - / the poor fellow falls down all the time"” ("“Von tot igraet khuzhe vsekh - / vse vremia padaet, bedniaga"'). As if to mock her suitor's intentions, Violet focuses on the "worst" player on the field rather than the "skillful" goal scorer, whom the protagonist emulates in vain. The soccer has inspired Nabokov's poetic persona, yet like an ineffective player he must cope with romantic defeat and his thwarted dream of love.

Following A University Poem, Nabokov soon hit his stride probing the joyful thrills of sports and the lofty dreams elicited by athletic action, most notably in Glory, his fourth novel, where the central protagonist Martin Edelweiss plays both tennis and soccer, while also trying his hand at boxing, skiing, and mountain climbing. These athletic activities are crucial to Martin's education and maturation, for sports provide the

\footnotetext{
${ }^{18}$ The translation is my own, but for Dmitry Nabokov's English translation of University Poem, see Vladimir Nabokov, Selected Poems, ed. Karshan, trans. Dmitry Nabokov (New York: Alfred A. Knopf, 2012), pp. 26-57.
} 
young hero- a Russian with a Swiss father (and surname) forced to live in the West after 1917 — the opportunity to develop his strength and courage in ways that will culminate with a risky, clandestine, and implicitly fatal journey into Soviet Russia. Athletics boost Martin's efforts to turn dreams into reality and romantic ideas into resolute action. Through these dreams, Nabokov weaves the zealous, ambitious spirit of athleticism into the metaliterary and faintly metaphysical fabric of the novel and thus transforms sports' aesthetic essence and requisite fortitude into art.

Martin—like Nabokov, a goalkeeper on a Cambridge soccer team and a tennis player-boasts an active imagination, yet, unlike Nabokov, he proves incapable of expressing his fantasies in words, as a writer might. Thus he resorts to physical, often athletic expression of his nascent, creative sense of self, as competition and the urge for athletic success prompt the young man's imagination and dreams of greatness.

Following an unsuccessful tennis match with a French tennis pro, to offer one example, Martin imagines a more advantageous result to the game: "On the way home [Martin] mentally replayed every shot, transforming defeat into victory, then shaking his head: how very, very hard it was to capture happiness!" (Glory, 47-48). Romantic dreamer and ardent athlete, Martin attempts to achieve a state of physical harmony and joy through both his dreams and subsequent action. In the foreword to the English translation of the novel, Nabokov calls Martin "that rarity—a person whose 'dreams come true"” (xii); indeed, this knack for turning dreams into reality manifests itself quite literally as Martin dreams of things that later seem to materialize. After Martin skis in the Swiss Alps, for instance, once back at Cambridge he has "dream-sped" (Glory, 75) down a snowy slope 
into Russia, an imagined return to his homeland that he will later realize through his daring journey into the Soviet Union.

In Glory, Martin's experience as a goaltender comes to the fore once his childhood dreams of athletic success materialize on the soccer fields of England, where he plays before Sonia Zilanova, a young woman he hopes to win over:

The action was taking place at the opposite end of the pitch, and he could revel in the cold air, in the mat green of the turf, in the chatter of the people standing just behind the goal net, and the glory of feeling that his boyhood dream had come true, ... and that there was somebody in the crowd for whom it was worth making a special effort. In childhood years sleep would overtake him just in those opening minutes of the game, for Martin would get so engrossed in the details of the preface that he never got to the main part of the text. (Glory, 110-11)

Endowing Martin with a goalkeeper's ethos of detachment similar to that later found in Speak, Memory, Nabokov depicts the athletic setting as removed from the temporal flow of everyday life and highly conducive to transforming romantic imaginings into tangible action (or, in the case of Speak, Memory, poetry). Childhood dreams of athletic glory have finally materialized for Martin on the soccer field, setting the stage for his romantic pursuit of Sonya (the one "for whom it was worth making an effort") as well as his adventurous plan to return to Soviet Russia. Quite significantly, mention of a "preface" and "main text" in this soccer passage suggests that sports underscore the metaliterary basis of the novel itself, for Martin's dreams, like so much in Glory, become reality and the imaginary becomes real within the narrative that is Martin's life; athletics compel Martin to conclude through bold action the "text" constituting his own heroic existence.

In the sports passages of Glory, Martin strives to actualize his dreams and affirm his physical presence before an implied spectator/reader. The athletic activity of Glory, Leona Toker suggests, lend Martin "flesh-and-blood solidity" (Toker, 106), as sports help 
him exhibit his individuality, fortitude, and physical vitality. At the beginning of Glory Martin struggles with a fear of failure and death, for it is remarked that "the possibility of a chance defeat made him so nervous, and he imagined it with such clarity, that never once did he try to start a wrestling match with [his] coeval" (Glory, 14), while on other occasions "he was so afraid of seeming unmanly, to become known as a coward," that he "firmly resolved to behave always as a fearless man would in his place" (Glory, 13). Martin often seems to perform before an unseen audience, as if aware of an extratextual spectator or reader. ${ }^{19}$ To emphasize Martin's heroic performance, Nabokov alludes throughout Glory to work by the Russian poet Nikolai Gumilev, whose poetic evocations of valor, manliness, adventure, and death provide a literary basis for Martin's romantic dreams of daring adventure - the feat, or podvig, constituting the Russian title of Nabokov's novel. ${ }^{20}$ Athletics resoundingly contribute to Martin's own bildungsroman, enabling the young hero to realize the powerful potential of both his body and creative consciousness. In a 1971 interview, Nabokov referred to Martin as one of his "favorite creatures, my resplendent characters," one of his "victors in the long run" (Strong Opinions, 193), and, indeed, this fictional victor triumphs by both athletically and imaginatively overcoming his deep-seated fear of defeat and mortality.

\section{"Intimations of Bliss"}

In Glory, Nabokov places athletics at the heart of Martin's journey from childhood to implicit death along the Soviet border. In fact, throughout a number of works—Glory, A University Poem, and later novels like Lolita and Pnin-Nabokov

\footnotetext{
${ }^{19}$ Martin also enjoys competing before an audience, be it the crowd at a soccer game or onlookers at a tennis court ("Spectators gathered around the court and this pleased him" [Glory, 47]).

20 "The heroic spirit of Gumilev," Vladimir Alexandrov suggests, "permeates Glory" (Alexandrov, 224).
} 
equates the aesthetic, epiphanic impulse of sports with movement into an otherworldly, eternal realm. Sports emphatically generate what Vladimir Alexandrov has described in his discussion of Nabokov's metaphysical conception of epiphany as "a sudden fusion of varied sensory data and memories, a feeling of timelessness, and intuitions of immortality" (Alexandrov, 7), all of which prevail in Nabokov's sports scenes to varying degrees. In such occurrences, the athleticism proves inspirational and revelatory, as the intensity of the athletic experience enables Nabokov's athletes-Martin, Lolita, and Pnin— to transport both themselves and spectators, such as the narrator or reader, into a state of otherworldly, aesthetic bliss, thus accentuating the lofty significance of athletics and sports spectatorship within the writer's metaphysical notions of artistic beauty.

In his foreword to the English translation of Glory, Nabokov explained in 1970 that "the purpose of my novel...lay in stressing the thrill and the glamour that my expatriate finds in the most ordinary pleasures" (Glory, $\mathrm{x}$ ), of which sports must surely be included, given how often Martin appears on a tennis court, a soccer field, or a mountain trail. Early on in the novel, having hiked up to a mountain precipice overlooking Yalta, Martin experiences "an unbearable intensification of all his senses, a magical and demanding impulse, the presence of something for which alone it was worth living" (Glory, 20); Martin similarly enjoys these intense, life-affirming sensations when parrying a soccer ball or volleying a tennis ball. Preparing for a soccer match while a student at Cambridge University, Martin "felt a beloved blend of impressions: the sharp smell of the damp turf, its resilience underfoot, thousands of people in the stands, the black bare spot in front of the goal, and the thud of the ball kicked around by the other team" (Glory, 110). Along with physical exertion and competition come heightened 
impressions and unadulterated thrills, which Nabokov's narrator replicates for the reader/spectator. Moreover, Martin will experience similar thrills when encountering literary allusions to sports when studying literature at Cambridge and reading Horace's Odes: "Here, too, Martin found intimations of bliss; how thrilling was that humdrum exchange about weather and sport between Horace and Maecenas" (Glory, 62). Martin, Nabokov emphasizes, is neither poet nor artist, yet he boasts an appreciation of detail that verges on the epiphanic, as the young man, providing an expedient model for Nabokov's reader, relishes the seemingly ordinary, "humdrum" particulars of sports that will inspire his subsequent feats of bravery.

Nabokov's A University Poem, much like Glory, provides a spectatorial brand of athletic inspiration, as the focus of this long narrative poem shifts from the soccer field to the tennis court, where the protagonist finally kisses the Englishwoman Violet, who "despondently" ("unylo") tosses about in his arms. The tennis, like the earlier mentioned soccer passage from A University Poem, reflects the romantic orientation of both participants: while the protagonist emerges as a "passionate player" ("plamennyi igrok"), Violet hits listlessly, prompting Nabokov to contrast her game negatively in stanza 34 with that of the great tennis champion Suzanne Lenglen. Via the beauty and speed of Lenglin's tennis strokes, the narrator of A University Poem rises majestically above his romantic frustration:

Она лениво-значит, скверноиграла; не летала серной, как легконогая Ленглен.

Ах, признаюсь, люблю я, други, на всем разбеге взмах упругий богини в платье до колен! Подбросить мяч, назад согнуться, молниеносно развернуться, и струнной плоскостью сплеча
She lazily - that means poorlyplayed; she did not fly like a chamois, like the fleet-footed Lenglen. Oh, I confess I love, my friends, at a full run the elastic stroke of the goddess in her knee-length dress! To toss up the ball, to bend back, to turn around with lightning speed, and with the strung plane from the shoulder 
скользнуть по темени мяча, и, ринувшись, ответ свистящий уничтожительно прервать,на свете нет забавы слаще... В раю мы будем в мяч играть. to hit the crown of the ball, and, having advanced, to devastatingly volley the whistling return,-on earth there is no sweeter pastime... In heaven we will play ball.

Alluding to the fashion sensation that the "goddess" Lenglen made in 1919, when she appeared at Wimbledon sporting a risqué (for the time) knee-length dress, Nabokov lyrically mixes sports and sensuality in a manner that anticipates the famous tennis passages of Lolita. As he will do when describing the young Lolita's tennis game, Nabokov joyfully proceeds from the sensual to the athletic and artistic and then on to the divine, presenting the tennis as epiphany; Lengelin's exquisite strokes and alluring artistry on the court transport the narrator, who is both observer and athlete here, as well as the reader into the lofty, eternal realm of "heaven."

The artistic, metaphysical effect of athletics on the implicit spectator proves particularly germane to Nabokov's Lolita. Sports abound throughout Lolita-swimming, rope jumping, horseback riding, downhill skiing, and even golf factor into the plot—but it is tennis that provides the novel its most memorable athletic game. In two celebrated passages devoted to tennis, Nabokov underlines the beauty of the sport, as the narrator Humbert Humbert observes his tennis-playing nymphette with an appreciative eye and eloquence that temporarily eclipses the pedophilia so central to the novel's plot. The two tennis passages of Lolita appear in Part Two of the novel, the first occurring in Arizona (with several references to subsequent tennis lessons in California) and the second occurring some 18 months (and 70 pages) later in Colorado. From the first to the second tennis scene, young Lolita, like one of Nabokov's butterflies, undergoes a transformation 
as she blossoms into a skillful tennis player. ${ }^{21}$ In addition to presenting an unexpected window into the girl's resilient character and unfortunate plight, Lolita's tennis (which Nabokov himself referred to as one of "the nerves of the novel") accentuates the transformative power of athletics, as tennis strokes become timeless acts of grace, elegance, and artistry for both Humbert and the reader/spectator. ${ }^{22}$

In the initial tennis passage of Lolita, Nabokov begins by mentioning some "very expensive lessons with a famous coach, a husky, wrinkled old-timer" (Lolita, 162), to whom Humbert turns for Lolita's tennis instruction after Arizona. Offering a veiled portrait of former U.S. champion Bill Tilden, a tennis great from the 1910s and 20s, Nabokov alludes to Tilden's alleged homosexuality with a punning reference to this coach's "harem of ball boys" (Lolita, 162). While it is easy to see the sexual, à la Rowe, in this pun on Tilden's homosexuality, it should be noted how swiftly Nabokov shifts in this same passage from the sexual to the celestial. Humbert remarks: “...but now and then, when, in the course of a lesson, to keep up the exchange, he would put out as it were an exquisite spring blossom of a stroke and twang the ball back to his pupil, that divine delicacy of absolute power made me recall that, thirty years before, I had seen him

\footnotetext{
${ }^{21}$ As Alexandrov discusses in his analysis of Nabokov's metaphysics, Humbert experiences a "clairvoyant vision" (Alexandrov, 173) of the future (and past) when he approaches the Arizona tennis court with drinks for Lolita and her young tennis partner. Nabokov describes how Humbert, observing "that the tennis court was deserted," not only "saw Charlotte's face in death," but also "noticed Lo in white shorts receding ... in the company of a tall man who carried two tennis rackets" (Lolita, 163). A dying Charlotte, Lolita's mother, had warned Humbert that he would lose his young nymphette, and it is this vision of loss that briefly materializes before Humbert's eyes as he sees the "tall man" (a reference to Quilty, Humbert's "double" - tennis pun intended - and rival for Lolita) leading the 14-year old away. This vision, Alexandrov argues, anticipates the later tennis scene, given how Lolita, who wears slacks in Arizona, briefly appears in the "white shorts" she will wear in Colorado, while a tall man will indeed join Lolita for a game of doubles in Colorado when Humbert is called away to answer a prank phone call.

${ }^{22}$ Nabokov, "On a Book Entitled Lolita," in The Annotated Lolita, ed. Alfred Appel, Jr. (New York: Vintage Books, 1991), p. 316. In Speak, Memory, Nabokov similarly used tennis as a means for probing the character of his older brother Sergei, a sibling he admitted never sufficiently understanding: "The only game we both liked was tennis...He was left-handed. He had a bad stammer that hampered discussions of doubtful points. Despite a weak service and an absence of any real backhand, he was not easy to beat, being the kind of player who never double-faults, and returns everything with the consistency of a banging wall" (Speak, Memory, 258). Sergei, a homosexual, died in 1945 in a German concentration camp.
} 
in Cannes demolish the great Gobbert!" (Lolita, 162). In addition to revealing Nabokov's familiarity with tennis history (the French champion André H. Gobert was one of Tilden's main rivals in the 1910s), this description of the coach's "exquisite," flowering strokes reveals a sudden transcendence through sports into the realm of the "divine," as the paradoxical, yet evocative "delicacy of absolute power" in Tilden's game evokes the first of Humbert's epiphanies that will occur as he watches the tennis. ${ }^{23}$

Lolita's tennis game, by the start of the second passage, has improved markedly. In the altitude of Colorado, Humbert is suddenly mesmerized by Lolita's tennis, which through its elegance and artistry produces in Humbert "the teasing delirious feeling of teetering on the very brink of unearthly order and splendor" (Lolita, 230). Hyperbolic and sexually implicit perhaps, but nevertheless a description that conveys the narrator/spectator's epiphanic, "unearthly" rapture over Lolita's evolving game and athleticism. Tennis has transported Humbert out of his self-centered world of pedophilia and inspired him to contemplate metaphysical issues of death and posterity: "No hereafter is acceptable," Humbert exclaims, "if it does not produce her as she was then, in that Colorado resort between Snow and Elphinstone, with everything right: the white wide little-boy shorts, the slender waist ..." (Lolita, 230-31). Reflecting an inclination toward a metaphysical ideal—where "everything" is "right"—and a presentiment of immortality similarly evoked in A University Poem, the Colorado tennis passage builds upon the sensual, physical essence of the tennis, as well as its beauty, to highlight the timeless artistry of sports and their ability to transport spectators—and readers-into this timeless realm. Accordingly, Humbert regrets not having captured Lolita's strokes on celluloid to document this exalted, voyeuristic state of sports spectatorship: "Idiot, triple idiot! I

\footnotetext{
${ }^{23}$ Nabokov also mentions here Max Decugis and Paul de Borman, two other tennis greats from the 1910s.
} 
could have filmed her! I would have had her now with me, before my eyes, in the projection room of my pain and despair!" $\left(\right.$ Lolita, 231).$^{24}$ Humbert wishes to prolong the voyeurism, but words will have to suffice.

What especially enthralls Humbert is Lolita's tendency to ignore the competitive essence of tennis yet blissfully relish the play and artistry so integral to the sport. In Humbert's rendering of Lolita's elegant tennis game, the fourteen-year-old girl comes across as more poet than athlete. A poetic subtext, for instance, prevails as Humbert explains how Lolita's “overhead volley was related to her service as the envoy is to the ballade" (Lolita, 232), the envoy being a short stanza that concludes a ballade. Later, a "syncope" (Lolita, 234)— the omission of sounds or letters in a word-will occur in a rally between Humbert and Lolita. Rhythm similarly figures in the lengthy description of Lolita's play, for "she would wait and relax for a bar or two of white-lined time before going into the act of serving" (Lolita, 231); and she would cover "her half of the court with wonderful ease, once she had entered into the rhythm of a rally and as long as she could direct that rhythm" (Lolita, 232-33). Furthermore, Lolita's tennis emerges as a celebration of artistic defamiliarization: when entering Lolita's "aura," the tennis ball "became somehow whiter, its resilience somehow richer" (Lolita, 231), seemingly enhanced by the deft touch of an artist. And when serving, Lolita "smiled up with gleaming teeth at the small globe suspended so high in the zenith of the powerful and graceful cosmos she had created for the express purpose of falling upon it with a clean resounding crack of her golden whip" (Lolita, 231-32). Like a deity using a "golden whip," Lolita has "created" with her racquet an imaginary, aestheticized reality—a

\footnotetext{
${ }^{24}$ Quilty later tempts Lolita with "a bit part in the tennis-match scene of a movie picture based on a play of his-Golden Guts..." (276). For more on the intersection of tennis and cinema in Lolita, see Appel, Nabokov's Dark Cinema (New York: Oxford University Press, 1974), p. 150.
} 
"cosmos" - that evokes in the spectator Humbert pure otherworldly delight. Her tennis, Humbert gushes, is "the highest point to which I can imagine a young creature bringing the art of make-believe" (Lolita, 231). Thus Lolita's tennis ultimately emerges as an artistic revelation for Humbert (and the reader), as Nabokov's narrator vividly describes her transformation on the tennis court.

In Pnin a similar transformation occurs before the novel's narrator when Timofey Pnin picks up a croquet mallet. Earlier in the novel, Pnin had boasted of once being " "a champion of kroket"' (Pnin, 106), and now Nabokov's eponymous sportsman flaunts his athletic skills at the summer home of some fellow Russian émigrés. Whereas throughout most of the novel, the narrator treats Pnin with derision, he suddenly switches to a more respectful tone, the tone of an admiring onlooker. And just as Lolita blossoms before Humbert's eyes when playing tennis, Pnin is "transfigured" (Pnin, 130), in the words of Nabokov's narrator, once he appears with croquet mallet in hand. "From his habitual, slow, ponderous, rather rigid self," this narrator explains, "[Pnin] changed into a terrifically mobile, scampering, mute, sly-visaged hunchback" (Pnin, 130). Nabokov, as he does in Lolita, endows his protagonist with an artist's tools and acumen within the athletic arena, as "Pnin foreshadowed every stroke with nimble aim-taking oscillations of the mallet head, then gave the ball an accurate tap, and ... with the ball still rolling, walked rapidly to the spot where he had planned for it to stop" (Pnin, 130). Pnin, like a writer, has "foreshadowed" each swing of the mallet while assuming a self-assured, even aggressive demeanor virtually absent elsewhere in the novel, thus underscoring the power of athletics to enrich everyday reality and elevate the athlete as well as audience. 
Throughout the croquet passage of Pnin, the seemingly innocent summer game takes on broad significance. The match has suddenly become athletic spectacle, as Pnin's deft croquet shots evoke "cries of admiration from the onlookers" and compel a passerby to shake "his head appreciatively" (Pnin, 130). He runs his balls through hoops "with geometrical gusto" (Pnin, 130), bangs the other balls off the court, and wins handily. But as in Lolita and Glory, a presentiment of death and the afterlife lurks in the background of Pnin's triumphant display on the croquet court. Immediately following this triumph, the narrator—implicitly a writer—describes Pnin briefly experiencing "a certain extremely unpleasant and frightening cardiac sensation" (Pnin, 131), yet as Nabokov's narrator notes, "it was not pain or palpitation, but rather an awful feeling of sinking and melting into one's physical surroundings" (Pnin, 131). Pnin's athletic exertion therefore leads to a premonition of the afterlife and the narrator's sense that the athlete has merged with his "physical surroundings," an athletic transfiguration that the reader witnesses in all its heart-wrenching pathos.

For Nabokov, the writer could learn quite a lot from the athlete. In exploring sports, Nabokov approximated the imaginative act of writing with the physical action of sports. Whether in "Breitensträter - Paolino," where the boxers' jabs and faints correspond to the young writer's creative style and skills, in "Football" and Speak, Memory, where the goalkeeper finds inspiration for his own verse, or in Lolita and Pnin, where the narrators - both implicitly writers — discover a transformed world when watching athletes in action, Nabokov saw the artist playing a game modeled on the athlete's every move. Observing sports, Nabokov's fictional writers likewise ascertain an 
energy and aptitude that they apply to their own work. This is particularly evident in The Gift (Dar, 1937), Nabokov's final Russian novel and, arguably, his most overtly metaphysical—and metaliterary—work, where a range of leisurely, yet physical activities, from tennis to picnics, inspire the writer-protagonist Fyodor GodunovCherdyntsev: "Bicycling and riding, boating and bathing, tennis and croquet; picnicking under the pines; the lure of the water mill and the hayloft — this is a general list of the themes that move our author" (The Gift, 27). More a spectator than a participant in these various activities, Fyodor observes the physical—and highly athletic_—world around him with a careful eye before infusing his art with all that he sees and appreciates. Nabokov would do much the same, as he placed his readers up in the stands, at a perfect distance to themselves delight in the impressive strokes and sidesteps of the writer's creative, energetic, and ultimately otherworldly game.

Alexandrov, Vladimir. Nabokov's Otherworld. Princeton, NJ: Princeton University Press, 1991.

Barabtarlo, Gennadi. Phantom of Fact: a Guide to Nabokov's Pnin. Ann Arbor: Ardis, 1989.

Dolinin, Aleksandr. “Istinnaia zhizn' pisatel'ia Sirina.” In Vladimir Nabokov, Sobranie sochinenii russkogo perioda v piati tomakh. Vol. 1. St. Petersburg: “Simpozium," 2000.

Gumbrecht, Hans Ulrich. In Praise of Athletic Beauty. Cambridge, Mass.: Belknap Press of Harvard University Press, 2006.

Karshan, Thomas. "December 1925: Nabokov Between Work and Play." Nabokov Studies 10 (2006). 
---. Vladimir Nabokov and the Art of Play. New York: Oxford University Press, 2011.

Larmour, David H. J. "Getting One Past the Goalkeeper: Sports and Games in Glory." In Larmour (ed.), Discourse and Ideology in Nabokov's Prose. New York: Routledge, 2002.

Nabokov, Vladimir. "Braitenshtreter - Paolino.” In Nabokov, Sobranie sochinenii russkogo perioda v piati tomakh. Vol. 1.

---. The Gift. Trans. Michael Scammell. New York: Vintage, 1991.

---. Glory. Trans. Dmitri Nabokov. New York: Vintage International, 1991.

---. Lectures on Russian Literature. Ed. Fredson Bowers. New York: Harcourt Brace Jovanovich/Bruccoli Clark, 1981.

---. Pnin. New York: Vintage International, 1989.

---. Speak, Memory: An Autobiography Revisited. New York: Vintage International, 1989.

---. The Stories of Vladimir Nabokov. New York: Vintage, 1995.

---. Strong Opinions. New York, McGraw-Hill, 1973.

Rowe, William. Nabokov's Deceptive World. New York: New York University Press, 1971. 